\title{
The Three Value Proposition Cycles of Equipment-Based Service
}

\author{
Laura Smith $^{\mathrm{a}}$, Irene $\mathrm{Ng}^{\mathrm{b}}$ and Roger Maull ${ }^{\mathrm{a}}$ \\ ${ }^{a}$ University of Exeter (UK), ${ }^{b}$ University of Warwick (UK)
}

\begin{abstract}
:
This paper contributes to the emerging discipline of service science through an empirical investigation of value propositions as connections between service systems. The starting point for our research is that service science is an interdisciplinary approach to the study, design, and implementation of service systems, a service system being considered a dynamic configuration of resources (people, technology, organisations and shared information) that create and deliver value between the provider and the customer through service (IfM and IBM 2008). Specifically, this paper investigates value propositions in the context of equipment-based service systems. Our qualitative findings identify three value proposition cycles; Recovery, Availability and Outcome. In so doing, showing that provider's offer three distinct propositions of value with three different primary transformations. This research contributes to theory in service systems by identifying value propositions as multiple, simultaneous and iterative connections between provider and customer systems.
\end{abstract}

Key Words: Service Science; Systems; Value Proposition; Qualitative

\section{Introduction}

The service sector now accounts for more than $75 \%$ of the economies of western industrialised nations. This transformation of the world's economy from traditional sectors to service has bought about a change in the nature of the organisation. Historically, research has supported the manufacturing sector (e.g. in engineering, management, technology etc.) and as such has focused on the technology and techniques that enable organisations in the manufacturing economy to function effectively and productively. However, even traditional manufacturing companies now attribute more 
than $50 \%$ of their revenues to service and it is becoming apparent that there is a lack of research and knowledge in service. In particular, the technology, knowledge and expertise required for an organisation to deliver service that may include intangible value propositions which by definition are perishable by nature and heterogeneous in characteristic is clearly deficient ( $\mathrm{Ng}$ et al. 2011a).

It is widely recognised that service research has not kept up with the demands of the economy (Grönroos 2001). In response, Chesbrough and Spohrer (2006) put forward the 'Grand Challenge' of service science, a common set of research problems meant to unite multiple groups in a common cause set to re-balance research and knowledge with the needs of the changing economy. What began as a 'call to action' has now become a global initiative in service science or Service Science, Management, Engineering and Design (SSMED) research. This emerging discipline advocates an interdisciplinary approach to the study, design, and implementation of service systems. Whereby, a service system is considered to be a dynamic configuration of resources (people, technology, organisations and shared information) that create and deliver value between the provider and the customer through service (IfM and IBM 2008).

Extant literature in service science has provided researchers with a manifesto, a common cause and a set of questions from which to base an integrative discipline focused on service systems. One of the latest calls in service science comes from Ostrom et al. (2010) who, in an 18-month effort, put together a set of global, interdisciplinary research priorities from academia and practice that is focused on the science of service. They found that one of the key priorities for progressing service science research is knowledge for measuring and optimising service value; specifically, how companies measure the value of service and what factors can enhance service value. Six topic areas were highlighted as being worthy of further research: Measuring the value and return on investment from service; creating and enhancing tools for capturing the value-in-use for services and communicating value to customers and throughout the provider; integrating service value and the costs of service delivery into joint optimisation models; creating and enhancing service standards and metrics that link to financial outcomes of the provider; managing the sales and service channel portfolio to maximise value; integrating the role of customers, employees, and technology for value optimisation. In essence, calling for an investigation into how providers should approach the creation, delivery and 
measurement of value between the provider and the customer through service, the very fundamental nature of a service system.

As already noted a service system is defined as a dynamic configuration of people, technology and organisations connected by value propositions and shared information. To develop theory on service systems, research is required which investigates the nature of the service system, how they arise and evolve, the relationship between systems and the role of people, technology, value propositions, and shared information (Spohrer et al. 2007). Spohrer et al. (2007) state that according to a 2003 report by the US National Academy of Engineering, one of the ways academic researchers ought to begin to focus on the needs of service businesses' is by adapting and applying systems concepts and methodologies. They go on to echo this sentiment for the development of service science and its study of service systems. In investigating the role of systems concepts and methodologies in theory development, $\mathrm{Ng}$ and Wild (2009) suggest that service research has a history of interest in systems (e.g. Chase 1978, Wemmerlov and Hyer 1989) and that the development of work in service science has renewed this interest (Demirkan and Goul 2006, Qiu 2009, Spohrer et al. 2007). Consequently, a systems approach to modeling and understanding service is becoming well established, (see Barile 2009, Barile and Polese 2009, Golinelli 2010, Ng et.al. 2011a, Ng et al. 2011b). Importantly, $\mathrm{Ng}$ et al. (2011a) propose that taking a systems approach to the study of service science may increase the research community's ability to develop a level of abstracted knowledge that will allow for transferability of knowledge, replicability of design and scalability for service knowledge across sectors.

Preceding Ostrom et al. (2010) and under a similar motivation, IfM and IBM (2008) drew upon the expertise and experience of leading academics and senior practitioners and proposed that researchers should establish service system and value proposition as foundational concepts. As a result of these latest calls in service science, a primary motivation for this study is to explore value propositions in equipment based service systems. With this in mind, and taking into consideration the need for a systems approach, we draw upon the literature on value and systems thinking.

The study will be presented as follows; we first review the literature on customer value creation with a particular focus on value creation in equipment based service systems. 
This is followed by a review of systems thinking literature. In considering the service science calls of Spohrer et al. (2007), IFM and IBM (2008) and Ostrom et al. (2010) and through the exploration of the value and systems thinking literature, we identify two research questions. First, what value is proposed by the provider systems when value is considered endogenous? Second, when value is considered endogenous to the provider system, what is the effect on the system? We then go on to describe the use of a qualitative method to investigate these questions. An explanation of method is subsequently followed by findings of the qualitative analysis and finally, we discuss the implications of these findings for service systems thought and practice and how this might be used to further research in service science.

\section{Value Creation in a Service System}

As discussed, in the study of service science, value propositions are thought to provide connections between service systems. In order to explore value propositions, we first look to the value literature as a means by which to explore the concept of 'value'. The creation of value is often thought of as a fundamental cornerstone of the management discipline (Albrecht 1992, Alderson 1957, Anderson and Narus 1999, Doyle 2000, Drucker 1974, Woodruff 1997). Moreover, it is often argued that it is the role of marketing to assist the provider in the creation of value for its customers, value that is superior to its competition (Tzokas and Saren 1999: 53). Yet, within marketing and academic literature in general, there is a lack of conceptual consensus on value and in particular, on customer value. Divergent approaches and perspectives on value exist in many disciplines, including economics, psychology, sociology, semiotics, finance, management strategy, marketing and law (Payne and Holt 2001, Wikstrom and Normann 1994, de Chernatony et al. 2000). Resulting in fragmented streams of thought and research on what value is and how it is created. It is unsurprising then that providers often do not know how to define the value they propose, or indeed how to measure it (Anderson and Narus 1998). As a consequence and particularly in the wake of service science, the study of customer value is becoming significantly more important, both in research and in practice.

In the management literature, many authors have approached customer value as an organisationally directed concept, in which the question of the value of a customer to the provider is addressed. This dictates a focus not on the creation of value for the customer 
but on the value outcome that can be derived from providing and delivering superior customer value (Payne and Holt 2001). As Payne and Holt (2001) argue, the major potential weakness of this approach is that it considers customer value only from the stance of how much value can be derived by a company from its customers; equally, the value delivered by the company to the customers needs to be considered.

In this respect, numerous researchers have suggested ways in which to define value from the customer's point of view (e.g. Anderson et al., 1993, Christopher 1982, De Rose 1991, Ravald and Grönroos 1996, Woodruff and Gardial 1996, Zeithaml, 1988). In searching for consistency amongst these definitions, Woodruff (1997) finds a number of areas of consensus. First, there is consensus that customer value is inherent or created in the use experience, which is sometimes referred to in earlier literature as the consumption experience. Second, that customer value is something perceived by customers rather than objectively determined by a seller, and finally, that perceptions of value typically involve a trade-off between benefits received and what was sacrificed in order to realise those benefits (e.g., price, effort, time). Folloing this review, Woodruff (1997) goes on to propose a definition of customer value seen by many as one of the most comprehensive as it captures the dynamic and context-dependent nature of how customers judge value, the criteria they use to do so, and the relative importance they place on such criteria (Parsuraman 1997, Payne and Holt 2001).

'Customer value is a customer's perceived preference for and evaluation of those product attributes, attribute performances, and consequences arising from use that facilitate (or block) achieving the customer's goals and purposes in use situations.' (Woodruff 1997: p.142)

If we consider customer value in this way, and if providers seek superior competitive through a superior value offering to its customers, providers must acknowledge two things. First, that a provider can only propose a potential value to the customer. This is because realised value is determined subjectively by the customer, realised in the use experience and is an evaluation of the benefits received against the customers resources invested to realise them. Therefore, it cannot be objectively determined or delivered by the provider in isolation (Vargo and Lusch 2004:2008). Second, to propose superior value offerings, providers must consider the customers realisation of value in the use 
experience. By setting the boundary of value as that which is merely a product or service delivered by the provider misses the understanding of the contextual nature of value within the customer's space which could aid providers in the proposition of superior value (Vargo and Lusch 2004, 2008, Ng et al., 2009).

If a provider's offering is predominantly tangible - for example a piece of equipment setting a boundary of value to exclude the customer context of use is arguably acceptable, as the time required to adapt the value of equipment to fit within contextual use may not be possible and any modification to the equipment can only be achieved in future design ( $\mathrm{Ng}$, et. al. 2011c). If providers draw a boundary around customer value in this way, customers must learn to use, maintain, repair, and adapt the equipment to their unique needs, usage situation, and behaviours. However, providers often package equipment with service support and therefore certain activities previously undertaken by the customer, for example maintenance or spares forecasting, become part of the providers responsibility. Therefore, customer use, needs, environment and behaviours are part of the provider's responsibility. In this situation, it is clear there is a need to draw a wider boundary around what value is proposed by the provider. As a result, the traditional notion of customer value as that which is exogenous to the provider system needs to change.

\subsection{Value Creation in Equipment-Based Service}

The provision of equipment has been an important aspect of the economy since the start of the industrial era. Most notably, Adam Smith (1776) proposed that the wealth of nations was built upon a country's ability to produce an excess quantity of goods and then export this excess to generate wealth. The political economy created by such a fundamental philosophy has been the reason for the dominant view of goods as the basis for value creation.

Over time, as equipment provision has became more complex and as competition has heightened, providers have felt the pressure to add value, predominantly through the provision of services. In light of this, research has shown that manufacturers now provide services in the form of training, integration with clients' capabilities, consultancy and other services related to the provision of equipment (Ren 2009). Furthermore, Chase and Erikson, (1988) identify four roles for service within a manufacturing environment; 
laboratory, consultant, showroom and dispatcher and their implications for customer satisfaction and factory performance. In fact, for many manufacturers to remain viable, research has shown that they may need to diversify into the provision of services (Neely, 2008). This provision has been commonly referred to as the servitization of manufacturing. Servitization has been discussed widely, frequently through an examination of the move by manufacturers to generate greater returns by providing through life support for their products (Vandermerwe and Rada 1988, Matthyssens and Vandembempt 1998, Anderson and Narus 1995). The hazards and enablers to the process of servitization have also been studied (Oliva and Kallenborg 2003, Mills et al., 2008). However, due to the established paradigm from the industrial era that production of goods is the basis of wealth creation, much of the discussion and analysis of engineering service has been through the lens of a traditional goods-based thinking, "because manufacturing has been the dominant economic force of the last century, most managers have been educated through experience and/or formal education to think about strategic management in product-oriented terms. Unfortunately, a large part of this experience is irrelevant to the management of many service businesses" (Thomas 1978). This raises the challenge for academics to question the assumptions upon which conclusions are being drawn. The nature of value and its role in the delivery of equipment-based service sits as one of its biggest challenges.

The use of equipment to realise value is often carried out by the customer away from the provider that originally manufactured it. Thus, manufacturers of equipment may be misled into thinking that value is merely the tangible offering and the responsibility of the provider ends at production or when ownership of the product has been transferred. This would be to consider value-in-use as exogenous to the provider system. In order to make value endogenous to the provider system, providers would need to consider value-in-use as a complete offering of the equipment-in-use, within the customer's space, to achieve the customer's goal (see Woodruff 1997). This means that the provider's responsibilities would need to include the customer and moreover the customer's capability to use the equipment in such a way as to facilitate the achievement of desired outcomes or goals. A traditional goods-centric mindset with boundaries of where 'production' ends may imply that the provider is only responsible for the delivery of 'service activities'. Such a mindset results in a lack of motivation to truly understand how customers realise value in 
collaboration with the provider, potentially resulting in poor outcomes and poor propositions of value.

\section{Value Delivery in a Service System}

The consideration of 'where production ends', is a boundary question. The consideration of the boundary ie the distinction of a system from its environment lies at the heart of systems thinking (Weinberg 1975, Checkland 1981, Van Gigch 1987). We can usefully distinguish between two types of systems, closed systems which have no interaction with their environment and open systems where 'things' such as material, people, and information are transacted across the systems boundary.

In the context of service science, Maglio et al. (2006) suggest that service systems range in scale from professional reputation systems of a single kind of knowledge worker, to work systems composed of multiple types of worker, to enterprise systems (for example, businesses), to industrial systems, to national systems, and ultimately to the global service systems. However, at each of these levels of scale, or abstraction, service systems are considered to be open. This is because they interact with the environment and indeed with other systems (for example the customer's system) through shared information and value propositions.

In this research we are considering the systems in use as an enterprise level open system. Katz and Kahn (1966) in their consideration of open systems describe an enterprise system, as consisting of five subsystems:

- Production/Technical: "the major type of work that gets done", the organisational 'purpose',

- Maintenance: socialisation of new members, training, preserving the system, rewards, aspects of the support processes,

- Supportive: transactions with external agencies,

- Adaptive: the research and planning activity e.g. market research, long-range planning, etc.

- Managerial: control, coordinate and direct subsystems, develop policies -- use both regulatory mechanisms (feedback) and authority structures decision making and implementation. 
Whilst this framework is useful at providing a basic structure for organisational analysis it doesn't provide a dynamic view of the organisation as an enterprise e.g. what are the interactions amongst the sub-systems and how is the organisation managed and controlled according to a purpose.

Perhaps the most intellectually robust and universally applicable of systems models is that proposed in Checkland, Warmington and Wilson's (1983) general systems framework for viewing the enterprise as a system (see Figure 1). In this model they develop the concept of an 'Integrated Production System' which transforms inputs into outputs, whilst explicitly recognising the applicability of the concept to service as well as manufacturing contexts. Unlike Katz and Kahn's (1966) model, Checkland et al. (1983) explore interactions amongst the sub-systems. To illustrate the enterprise model shown in figure 1 below, $T$ is the primary task and transforms inputs into outputs, $P$ is the planning system, $S$ is the support system, $C$ is the enterprise wide control system and $L$ is a linkage system to the external world and includes such activities as marketing, R\&D etc. Each of the sub-systems has its own local control system, depicted inside a smaller circle, also labelled C. Checkland et al. (1983) claim that an organisation can be organised in many ways but they must embody this basic systems model. In this model it could be argued that potential value in the provider system is proposed by the transformation ' $T$ ' and is communicated by ' $L$ ' the link to the environment, or in other words, to the customer.

[Figure 1 near here]

Although there are similarities to Katz and Kahn's framework, Checkland's is more dynamic in recognising the importance of the control system and the linkages between the sub-systems and this model is further developed into a depiction of the management control system (Figure 2 below).

[Figure 2 near here]

\section{Research Questions}

This research brings together the two concepts of customer value and systems thinking to explore what value propositions are offered to the customer by the provider system, 
specifically within equipment-based service. In so doing, the research questions build on the work of Spohrer et al. (2007), IFM and IBM (2008) and Ostrom et al. (2010) who call for a greater understanding of value propositions and service systems for the development of theory in service science. We have therefore developed the following research questions:

1. What is the value proposed by the provider system when customer value is considered as endogenous?

2. When value is considered as endogenous, what is the effect of value propositions on the provider system?

\section{Methodology}

A qualitative method was used to derive insights into the value proposed by equipmentbased service offerings. The purpose was to discover regularities in the potential value proposed by the equipment based service providers. Specifically, the research sought to identify (and categorise) valued elements of the equipment based service offering and explore their connections, internally to the provider system and externally with the customer. Under this motivation, a qualitative grounded theory approach is deemed appropriate (Miles and Huberman 1994). Due to the notion that the value proposition is a connection between systems, namely between the provider system and its customer community or target market, the unit of analysis is the connection between the provider and customer system's or in other words, the interaction. In order to investigate this connection or interaction we collect qualitative data from both systems on the unit of analysis, the value proposition. Accordingly, we collect qualitative data from the provider and from the customer. In order to control for context specific factors and bound the case, the data was collected from three large multinational organizations who all supply service support for large, high-value, low-volume equipment within the defence industry. Service revenue represents a high proportion of the annual turnover, at least $50 \%$, in all three organisations and therefore all propose comparable product-service offerings.

In terms of the type of data collected, qualitative research is often characterised by the use of multiple methods, often referred to as triangulation. As suggested by Dooley (2001) we use qualitative interviews, analysis of texts and documents, and recordings and transcriptions of interviews. The logic behind using multiple methods is to secure an indepth understanding of the phenomenon in question. 
Data were gathered through in-depth interviews with provider employees and customers, The selection of key informants is critical to the process of identifying and describing the value proposition. First, 24 employees involved in the delivery of equipment-based services were selected, primarily from asset/equipment management and customer-facing support roles (see Table 4), these roles were felt to encapsulate the ' $T$ ' and the ' $L$ ' in figure 1 and therefore were considered to have the strongest influence on the potential value proposed and communicated by the provider system. 21 customers of equipmentbased service were also selected, notably from a variety of roles within the customer community including equipment operators, who represent users of the equipment, purchasing managers who procure equipment and operations managers who will influence procurement and strategic use of the equipment. Such individuals are best placed to provide insight into the perceived value proposed by the provider system's offerings. A total of 45 in-depth interviews with employees and customers from three equipment-based service providers were conducted. An analysis of the participant roles is provided below in table 4 , from this table it is evident that individuals interviewed span the potential hierarchy of an organisation and encompass director, management and delivery level roles from both provider and customer systems.

\section{[Table 1 near here]}

The interviews were conducted over a period of 2 years, between the years of 2008 and 2010. The interviews lasted approximately 1-2 hours. Each interview was audio-taped and verbatim transcribed. Analyses of the verbatim interview transcripts followed a grounded theory approach (Strauss and Corbin 1990). In addition, the trustworthiness of the present research findings was assessed by applying the techniques of triangulation and informant feedback (Miles and Huberman 1994). First, the data was categorised by three researchers. Initially, into open codes which broke down the qualitative data into discrete elements of the providers offering, namely the service attributes. Followed by axial coding, in which categorisation was centred on distilling open codes in to generic sets of categories which were crucial in describing the phenomenon (see Strauss and Corbin 1990). The researchers' brief was to code and categorise for the purpose of theory building and knowledge transferability. At this stage, the results of all three researchers were compared to identify those areas where there was disagreement. All three 
researchers consistently identified three categories of value proposition. However, differences existed in terms of (1) the labeling and (2) the categorisation of service attributes within these categories. To resolve any inconsistency in labeling and the correct assignment of service attributes to the three value proposition categories, the researchers conducted a participant workshop to gather informant feedback. The study's methodology and findings were presented during a workshop with four interviewees. Participants received a description of the results and were asked to comment on how well the results reflected their experience and practices and whether they would recommend any changes. Only a few changes in labeling of value proposition categories and classification of service attributes were made after this final step.

\section{Findings}

\subsection{Findings: What is the value proposed by the provider system when customer value is considered as endogenous?}

Traditionally, equipment manufacturers have viewed their value offering as predominantly tangible, as a piece of equipment. Accordingly, the piece of equipment is offered to the market for customers to realise their own value, within the context of their own system. Drawing the provider boundary in this way ensures the provider system remains viable. However, equipment is very rarely packaged without service and support; in fact many equipment providers now attribute over $50 \%$ of their revenues to service. The result of this is that the customer's activities, and indeed the context within which the equipment is being used to achieve the customer's own goals, are being drawn within the provider's system boundary. As a result, customer value is becoming endogenous to the provider delivery system. When customer value is considered in this way, a customer's realisation of value that will enable them to achieve their own goals; in other words, the customer value system becomes an important factor of consideration in delivery.

Customer value is often equated to means-end theory, which posits that customers acquire and use products or services to accomplish favourable ends or goals (Khalfia 2004). Research on means-end theory in marketing can be traced back to work in consumer research (Rokeach 1973, Gutman 1982, Peter and Olson 1987, Wilkie 1994, de Chernatony et al. 2000). Whereas academics such as Gutman (1982) sought to understand buying behavior and decision-making of consumers in the purchase situation through a means-end chain (Payne and Holt 2001). Means, in this sense, are products or 
services, and ends are personal values considered important to consumers; means-end theory therefore seeks to explain how an individual's choice of a product or service enables them to achieve their desired end states (Khalfia 2004). The means-end chain has been shown to be equally applicable to organisational customers operating in a businessto-business market (Lapierre et al., 2008).

The seminal means-end model is Woodruff's (1997) Customer Value Hierarchy Model. According to Woodruff's (1997) definition, attributes, consequences and goals, or endstates, are three distinct levels of abstraction which combine to form the hierarchy model of value (Lapierre et al. 2008), as shown in Figure 3. Woodruff's (1997) hierarchy model is a means-end model since attributes and consequences represent "means" of attaining certain ends targeted by the customer. Attributes in this model are product, service or supplier characteristics that the customer values and wants to find in the offering (Woodruff and Flint 2003). Essentially, the customer wants attributes that in a particular use situation, brings consequences that are consistent with the goals and purposes he or she pursues (Lapierre et al. 2008). In this sense, attributes are valued because the consequences associated with owning or using them is valued. A consequence is desired if it produces a benefit or minimises a sacrifice (Gutman 1982, Lindgreen and Wynstra 2005, Lapierre et al. 2008). A consequence is desired, too, because it helps to achieve a goal or end-state consistent with the customer's values (Gutman 1982, Rokeach 1973).

[Figure 3 near here]

Three cycles of value creation in equipment-based service delivery emerged from axial coding of the interviews conducted (Fig. 4). In this section, these value proposition cycles are discussed; in particular focusing on where in the customer value model the three cycles propose to support the co-creation of customer value.

[Figure 4 near here]

\subsubsection{The Recovery Value Proposition Cycle}

The traditional support model for equipment usually encapsulates three separate contracts: a repairs contract, a spares contract and a post-design services contract 
(Hockley et al. 2010). The recovery value proposition cycle attributes found in this study follow the traditional support model. The service attributes were identified in the process of open coding and are shown in Table 1.

Through further analysis, these recovery cycle attributes are found to propose a value at the point of asset failure. As a result, this value proposition cycle is delivering to the bottom level of the customer value hierarchy. The provider is acting on individual assets to recover them to operable status and to minimise disruption which could cause undesirable consequences in the customers use experience. The potential value therefore resides in the provider's ability to recover quickly to a operable state. The following passage from an interview with a Programme Manager illustrates this point:

'What they want from us, undoubtedly, is a quicker service on the repair and overhaul and a more accurate spares delivery to enable their planning to work better. So that clouds a lot of their issues because that means if they can't output their (assets) as they would like them, they can't (use) their (equipment) etc.'

The potential value of fast recovery, is found to be due to the impact of the downtime on the customer's ability to use the equipment, the subsequent consequences of which are a risk to the customer's ability to achieve operational goals. It is notable, however, that any recovery is dealt with within the provider system and a operable asset is returned back to the customer for use and the realisation of the value of the asset outside of the provider system. This point is demonstrated in an interview with a Call Centre Manager on the nature of incoming issues:

'When we get those requests, we get a lot in on the basis of the (equipment) are (inoperable). So they're in a critical position. "Can you turn this around in a very short time frame?" When we do that, the response you get is, is very, very positive ... ... because, you know, without that piece of advice they can't (use) the (asset). So it becomes critical to, to their (operational) success, as it were.'

[Table 2 near here] 


\subsubsection{The Availability Value Proposition Cycle}

Hockley et al (2010) propose a reasonably simple definition for the delivery of equipment availability which they adapted from various standards (British Standards Institution 1991 and Defence Standard 00-49):

'The probability that the system or equipment used under stated conditions will be in an operable and committable state at any given time' (Hockley 2009).

This raises a few important concepts; first, equipment provision under stated conditions, therefore requiring a provider to define the function and the environment in which the equipment is being used. Second, the word operable implies that the equipment can be committed to an operation and start its intended use successfully (Hockley et al 2010). Therefore, availability proposes a different value to traditional support identified above because function and environment are considered endogenous to the provider system.

Open coding found a number of attributes, shown in Table 2, which deliver to availability. Further axial coding found that in contrast to the recovery cycle attributes, where the use of equipment to achieve benefits is conducted by the customer away from the provider that manufactured it, the availability value proposition cycle attributes support equipment-in-use. Therefore, supporting assets within the context of the customer environment. A Customer Account Manager articulates the notion of equipment-in-use when discussing the difference between traditional contracting models, like repairs-only contracts, and the way in which asset management strategies (the availability attributes) have changed practice:

'You can control the quality of (the asset) as it leaves the factory gates, you couldn't control the quality of it as it was in service. So, to an extent, we've actually got more control now than we previously had because when you're in the situation when you deliver a product... it goes into the customer's organisation and the gates swing shut and we're not allowed in, the quality of that product in operation is, or was to an extent, dependent on the customer's maintenance and management of it.' 
Supporting equipment-in-use means that the provider's transformation process includes the customer and the customer's capability to use the equipment, within 'the customer gates'. Take for example, the attribute 'Equipment Life Management Planning'; Equipment/Asset Manager are providing asset life advice for a customer's equipment in order to maximise the potential usage:

'The most difficult balance of all is knowing when to pull things from service. Every component in the (asset) starts deteriorating from the first second it operates and it will continue to deteriorate until the point comes at which they fail. If you allow them to fail, they do damage to other parts of the (asset) and they do damage to the customer... So you don't want that to happen. So you want to pull things out of service and replace them or repair them before they fail... However, in order to get the best value for the customer, you want them to stay in service for as long as possible because this component, whatever it is, cost a lot of money. If you remove it a year ... before it needs to be ... it's cost the customer that year and it's a constant balance between the best value to the customer without allowing a failure to happen which will have greater consequences.'

These asset management practices, shown here as availability attributes, are not just maximising potential usage but are taking into consideration the use of the equipment:

'We try to throw our (Asset) Management effort into it. So we go to see the customers and ... the first thing you try to do is you try and stop the (assets) getting rejected quite as quickly ... So we try and give some alleviation to let them keep (operating), basically ... You can also work on things like doing spares provisioning conferences. So where some of them are not ordering early enough you try and go see them... You can also do some technical aspects as well. So not just extension of limits, but you can look at certain specific (operations) they might be (undertaking) etc.'

In summary, the availability value proposition cycle attributes propose potential value through the maximising availability of equipment for use. In order to do this the cycle takes account of stated conditions and therefore, the availability value proposition cycle is supporting equipment-in-use and directly impacts on consequence-based satisfaction in 
the customer value hierarchy by ensuring availability and influencing desirable consequences in use.

[Table 3 near here]

\subsubsection{The Outcome Value Proposition Cycle}

In addition to proposing recovery and availability value, analysis also found that outcome value proposition cycle attributes go beyond availability to facilitate interoperable use of the provider's assets with other equipment, ultimately supporting the customer in the achievement of their own goals through improved capability. Therefore, the use of equipment to achieve benefits here is conducted by the customer in coordination with the provider that manufactured it. As a consequence, this cycle of attributes treats value-inuse within the context of the customer's environment as endogenous. This represents a complete offering of the equipment-in-use, within the customer's space. Thus, the provider system is recognizing and incorporating the customer's need for their equipment use to deliver to an operational goal. This is illustrated in the passage below, taken from an interview with a provider Customer Account Manager:

'The intention (is) that what the (provider) delivers is either zero failure in terms of (operational) outcome or minimising the impact on (operational) outcome. And that's a consequence of having the best products at delivery and the best service, such that you manage the volatility.'

In another example a customer Operations/Programme Manager explains the role of the equipment-based service provider in delivering capability towards operable outcomes:

'The end goal in this particular environment is to keep the (equipment in use) with the right capability so that the (equipment operator) can do what the (organisation) wants it to do. So that's the end, whether it's a good end or a bad end goal that's what we are here for.' 
The outcome value proposition cycle as a result proposes to support a customer's capability to achieve a desirable outcome, and is therefore creating goal-based satisfaction at the very highest level of the customer value hierarchy.

[Table 4 near here]

In summary, the findings show three distinct abstractions of value proposed by the provider system. First, a recovery value offered by minimising disruption; second, an availability value offered by maximising potential use and lastly, outcome value offered by supporting capability to better achieve desired outcomes.

\subsection{Findings: When value is considered as endogenous, what is the effect of value propositions on the provider system?}

In addition to identifying three distinct value propositions in equipment based service, our data identifies a number of effects on the provider system caused by there propositions. First, each value proposition has a different primary transformation (see table 5). Second, the three value propositions, while distinct in their proposition of potential value, are often acted upon by the provider system simultaneously. Lastly, delivery to the three value propositions is an interactive process between the provider system and the customer. Each of these findings is discussed in more detail below.

\subsubsection{Primary Transformations Across the Value Propositions}

The concept of primary transformation is found in the operations management literature and dictates that processes have one dominant transformation. That transformation could be an information processing operation, a material processing operation or a customer processing operation (Slack 2004). Qualitative analysis of the data on value propositions found that each of the three propositions of value has a different primary transformation.

Take for example the recovery value proposition cycle, as discussed; this value proposition is concerned with how the provider manages asset failures. As such, the primary transformation is primarily a material processing operation. The input to which is a broken or damaged part and the output is an operable piece of equipment. This is evident in the passage below taken from a Programme Manager, a circumstance is 
described in which a part is called in as damaged, sent back from to the provider, repaired and returned repaired to the customer:

'Say they've spotted a couple of nicks on one of the blades and basically the part has passed the limits contained in the manual... It's then sent back, gets inspected, we repair it and give it back to him'

In contrast, the availability proposition cycle is primarily an information processing operation. Value is proposed through the maximisation of equipment availability, rather than value in the minimising of any disruption of asset downtime. Increasing the availability of equipment is a challenging task. A critical input to which comes from understanding the equipment usage. To illustrate we refer to a passage taken from an interview with a Programme Manager, which discusses what is required in order to draw up a spares programme:

'I'd have to know what they're doing with it, how many hours they're running with it and what their plans are for it longer-term and also some records of the history of each of the (assets). So, once I've got that, then I can draw off a plan'

The outcome value proposition cycle is a completely different order of challenge and is primarily a customer processing operation. The concern here moves to capability rather than simply availability. In this event, the provider is now integrated with the customer system and provides continuous and ongoing advice on the best use of the asset as the environmental state changes. In order to do this a provider may transform customer, information and material to improve an outcome but primarily it transforms customer's actions and capabilities. A specific example of this type of practice is the offering of help and advice to customers on how best to configure their equipment dependent on the operational requirement a customer had. This was often provided through operating programmes which demonstrate how using certain assets, with certain availability in a given combination, would allow capability for a certain operational requirement:

'Using this (customer data and information on operational requirement) you can say "right, the operable assets - I could take that module, that module, that module 
and build an (asset) good for 200 (operable) hours and send it to (X operating condition). It probably will get to 200 hours but not much further'

\subsubsection{Simultaneity of Delivery}

Evidence showed that not only does each proposition have a different primary transformation but that these propositions are often enacted simultaneously. For example, a customer discusses the potential extent to which they treat the customer system as endogenous:

'It's really a question of how far those extend into the customer's organisation. It begins with the acquisition of material, all the way through, potentially, to managing the customer's fleet of equipment for them and the point at which you stop varies between customers and even within customers, it varies between products because, for instance, it's a lot easier for a customer to agree to outsource the training (equipment) than it is for them to outsource their (operational equipment). So even with those (customers) that have gone further down the route of industrialising the support, there will still be a difference between product lines as to how far they are prepared to go and you can understand why that should be'

\subsubsection{Value Propositions as Cyclical Interactions}

The three value propositions are described here as cycles, this reflects the nature of interaction observed between the provider system and the customer. The findings show that the value of equipment-based service is not an output of traditional delivery mechanisms where the customer is a passive recipient to delivery processes. Instead, value emerges from a cycle of iterative processes between the customer and the provider, with resources contributed by both parties. In this sense, the flow of the connection between the provider and the customer is bi-directional, creating feedback loops between the two systems. The availability and outcome value proposition cycles in particular have feedback loops with the environment because the proposition is realised (co-created) over a series of dependent interactions. In the recovery cycle this is less so because a piece of equipment fails, it is fixed generally exists in an independent interaction. 
The following passage taken from an interview with an Operation's Manager from the customer system demonstrates the 'multi-state' environment in delivering a capability to achieve customer outcomes, it shows how the provider created operating programmes daily adapting them in quantity, time and weather according to the customers system.

'We completed a contract for the maintenance and most of the (equipment) facilities to be owned over to a contractor... the (operating) programme was created on the day the (use) happened or the day before... So the (operators) or the trainers were making decisions about how many (assets) they wanted, at what time of day... they were flexible enough to offset against such things as bad weather'

In summary, these findings indicate that the notion of value and its achievement is different across all three value proposition cycles. This is illustrated in table 5 below. The cycles represent three distinct connections between the two systems, which interact.

[Table 5 near here]

\section{Discussion}

The customer value hierarchy and means-end theory assumes that the provider merely offers product specifications or service activity attributes in a value proposition to the customer, and that the customer learns preferences for those attributes based on their experience of how these perform in use, in their own environment, using their own resources. However, this study finds that when the customer's value is endogenous in the provider system, the company's proposition directly influences customer use and end states through the co-creation of desired consequences and capabilities to achieve outcomes. Previous studies have not looked at where the provider system interacts with the customer value hierarchy; they have only looked at the customer in isolation. More concretely, when value is considered as endogenous the move into co-creating customer goals or 'end-states' has an impact on the provider's system and it's transformation operation's. If providers propose and contract on availability or capability the use of customer resources to achieve higher level, more result-oriented end-states is undoubtedly necessary. This of course increases risk to the provider, as there is less control of the achievement of this type of outcome. As such, our study contributes to the understanding of value propositions as an interdependent connection between two 
systems through the discovery of three value proposition cycles combining and integrating their resources in the use of equipment towards excellent outcomes.

Furthermore, the findings of the study suggest that the notion of value and its achievement is different across all three value proposition cycles. In the recovery value proposition cycle, the provider's role starts at the point of equipment failure. This means that at the starting point of achieving value, the customer is already in a negative position. The highest level of success in such a value proposition cycle, even if the equipment is recovered within seconds, is already a negative outcome i.e. a disruption. The provider's ability within this value proposition cycle is to ensure that the disruption is minimised. In the availability value proposition cycle, achieving value is focused around ensuring equipment availability. This implies that the best outcome, i.e. at 100\% availability, is an absence of failure. The outcome to the customer is status quo. There is no positive impact to the customer's goals and operations, merely an absence of disruption. In the outcome value proposition cycle, achieving value is focused around contribution of the equipment towards better outcomes for the customer, optimised across other equipment and resources within the customer space, so that the customer is assisted to achieve their goals more efficiently and effectively. This clearly has a positive outcome (assuming the advice given is useful) to the customer, and success in the achievement of this value proposition cycle is a positive impact on achieving customer goals.

From an operations perspective, the material transformation is the core value proposed by a provider. This would equate with Checkland et al's ' $\mathrm{T}$ ' in the enterprise model (see figure 1). However, our findings also indicate the importance of information and people transformation to achieve value. Whilst Checkland et al. recognise that the transformation would depend upon the weltanschauung, or outlook, of the observer and that this might change over time, his model is based on a single primary task and the instructions for the development of a root definition are based on primary task analysis. Our results show that the organisations in our study have multiple primary tasks, in that they are providing multiple value cycles simultaneously and that the organisation must manage the tension between these multiple perspectives.

This notion of a primary task has permeated into operations management, which considers processes as having one dominant transformation; either information 
processing operations, material processing operations or customer processing operations (Slack 2004). This research has identified that equipment manufacturers may have all three transformations taking place simultaneously. That is, the repair cycle has material as its dominant transformation, the availability cycle has information as its dominant transformation, and the outcome value proposition cycle transforms the customer's actions and behaviours. This indicates a much more complex system with the interaction of information processing, customer processing and material processing needing to be synchronised. In terms of Checkland's management control system (see figure 2), our data indicates that the feedback mechanisms for each transformation exist in different cycles. For example, managing the recovery cycle often requires immediate action and is primarily a single transaction (e.g. when aircraft are unusable this can be within $24 \mathrm{hrs}$ ). In contrast, the availability and outcome cycles take place over a much longer timeframe and are co-created over multiple transactions between the provider and the customer. This would be easier to manage if each of the recovery, availability and outcome cycles were independent but given the simultaneity of cycles for individual customers this is unlikely.

This interplay of the feedback mechanisms between the provider and the customer system's for each of the cycles has implications for Checkland's model. The enterprise model now has three transformations that need to be integrated within one planning system and one enterprise wide control system. This may go some way to explaining the inherent challenges organisations face in transitioning from manufacturing to service. Neely (2008) drew on data from over 10,000 providers in 23 different countries has shown that although providers see an increase in revenue from servitization they also see generate considerably lower profits, which in the long term my threaten their survivability and proposed this may in part be caused by a fundamental change in value proposition.

Our research has also provided evidence of a key missing sub-system interconnection in Checkland et al's (1983) enterprise model that is between the linkage sub-system (L) and the transformation $(\mathrm{T})$. We have provided evidence that the external link from the customer has a direct link with the transformation, ' $\mathrm{T}$ '. ' $\mathrm{T}$ ' offers a value proposition to the environment and particularly in the case of the availability and outcome cycles the external environment is constantly feeding information back and modifying the 
transformation e.g. on equipment usage. This is a far more dynamic interplay than was described in the original depiction. Our data also provides evidences of the importance of this relationship, particularly in the availability and outcome cycles where the linkage to the customer is paramount in meeting the customer's outcomes.

Overall, we suggest that Checkland's enterprise model should play a significant role in the development of the service science community. Theoretical abstraction based on this model allows for transferability, replicability and scalability ( $\mathrm{Ng}$ et al. 2011a). We consider that Checkland's model meets these requirements and can be applied to any service environment, what remains to be considered is the developing of theory and managerial guidelines for highly complex environments that have a multiplicity of transformations and the implications for planning and control in complex systems eg those circumstances where the customer's outcomes are constantly changing and feedback mechanisms operate on different time scales.

Our study also contributes to the understanding of engineering capability, particularly around requirement analysis in systems engineering as well as customer inputs and variety. Requirement analysis involves activities that determine the needs or conditions to meet new products, taking into account conflicting requirements or user specifications. In a traditional approach, the customer, if asked for specification, would implicitly assume its most common states of use and the requirement analysis would be specified around such declarations. This puts the risk of changing use-states squarely on the customer since rigidities have been built into the design of the product to match the predetermined states. This also makes the product less agile in its use across states, but is acceptable in the traditional 'value' sense because it is what the customer wanted. When value is considered as endogenous, i.e. when the provider is delivering to outcomes, customers do not predetermine states. Instead, both the provider and the customer may wish to consider all states of use and every use state is probabilistic. The nature of customer inputs and the need to attend to variety of use become a joint activity with different set of processes linking the providers. The task for both the provider and the customer is to optimise the configuration of resources - both tangible and intangible - towards achieving outcomes across all states, in a partnered environment.

\section{Managerial Implications}


As equipment provision becomes more complex, providers have found the need to educate customers on the use of the equipment and create a better fit between the design of the equipment and customer usage. However, our study has highlighted the additional issue of customers' context of use would inevitably lead to situations of very high variety. The delivery to such a high variety of contextual use poses a major challenge to providers when they seek to 'add value' to their equipment through outcome and availability value (Ng et. al. 2011c). Does 'added value' imply better fit to the customer system to achieve better outcomes, taking over some of the customer processes to achieve the same outcomes? Or does it imply being able to tailor the provider's processes to support the delivery of outcomes across different states?

As discussed earlier, our study shows that if value is to be considered endogenous to a provider's delivery system, the provider has to factor in the customer's use of equipment. The challenge to the provider is that it now has to ensure that the equipment is able to achieve the customer's own goals which would require greater dependency on the customer and its resources ( $\mathrm{Ng}$ et al. 2009). In essence, a provider that takes value as endogenous to the delivery system has to have the capability to manage the customer, an area over which the provider may or may not have much control. A recent paper by $\mathrm{Ng}$ et al. (2010) suggests that this capability to co-create value is essential to competitive advantage. Consequently, the provider has to be empowered to think about its own capability as that which includes aspects of the customers' materials, information and people. The alignment of the two systems in co-creating value is paramount $(\mathrm{Ng}$ et al. 2010). Further research could build on value proposition interactions to investigate the concept of value co-creation between the provider and the customer system.

It is worthwhile noting that the value investigated here is functional value, and not the emotional value that could be perceived by the customer (cf. Mullens and William 2004). Future research could also address the emotional value of customer experience that could emerge from the interactions within the three value proposition cycles.

\section{Conclusion}

Spohrer et al's (2007) article on the steps towards a science of service systems stated that in order to develop theory in service science, research should explore the relationship between systems and the role of value propositions. As literature and momentum around 
service science has grown, research communities such as Ostrom et al. (2010) and IfM and IBM (2008) have drawn upon the expertise and experience of leading academics and senior practitioners to highlight research priorities for service science. As a consequence, it has been proposed that researchers should develop the foundational concepts of service system and value proposition. In order to make these investigations, Spohrer et al. (2007), $\mathrm{Ng}$ and Wild (2009) and $\mathrm{Ng}$ et al. (2011a), go further to say researchers should consider a systems approach. In particular, $\mathrm{Ng}$ et al. (2011a) propose that taking a systems approach may increase the research community's ability to develop a level of abstracted knowledge that will allow for transferability of knowledge, replicability of design and scalability for service knowledge across sectors. This paper contributes to service science through an empirical investigation of the value propositions that connect equipment based service providers with their customer. Moreover, we do so using a systems thinking approach.

Our findings show three distinct abstractions of value proposed by the provider system. First, a recovery value offered by minimising disruption; second, an availability value offered by maximising potential use and lastly, outcome value offered by supporting capability to better achieve desired outcomes. This is an important insight for equipment based service. It is important to note of course that value propositions will vary by context. However, the findings also pose insight for service science and the study of service systems. Namely, value propositions between provider and customer service system's are found to be multiple, simultaneous and iterative. Thus, there will be inherent effects for both provider and customer systems.

Future work in equipment based service should build on these propositions to explore their effectiveness, efficiency and sustainability for service system management (Spohrer et al. 2007). In particular, research should explore the effect of the different value propositions on the two service systems and how value is co-created between the two. In terms of the provider system, investigation of the ' $T$ ' and ' $L$ ' main subsystem link (see figure 1) may hold important insights for operations management.

The achievement of excellent outcomes, as opposed to excellent equipment, is through the contribution of resources provided by both the provider and the customer. The theory on manufacturing systems, processes and knowledge commonly excludes customer resources in delivering a manufactured good, and we propose that it is a necessity in 
order to extract the value inherent in the equipment. This approach may need to be adapted, and the access to and integration with a customer's system, its processes, information and knowledge are proposed as a necessity for the delivery of high quality service.

Our study suggests that the three value proposition cycles are an iso-morphism of how manufacturers' value propositions are evolving. They begin with a traditional understanding where the product is the equipment and service is the recovery of equipment failure, essentially the recovery value proposition cycle. They then evolve to a situation commonly found now where service is to prevent product failure and therefore surrounding the product with other support activities towards that end, essentially the availability value proposition cycle. Finally, we suggest that in the future these manufacturers will operate in an environment where there is a blurring of boundaries between product and service. This will be reflected in an integrated amorphous complex service system aimed towards achieving customer outcomes with equipment, technology and activities in co-creation with the customer, where the customers themselves are resource providers and integrators.

While delivering to outcomes brings about risks and is challenging to the provider (see $\mathrm{Ng}$ and Nudurupati, 2010), it can potentially bring about significant contribution to the sustainability agenda as the longer machines are kept working and equipment is kept operational, the less there is the need for production and consumption of new equipment, cutting carbon emissions overall (cf. Mullens and William 2004). However, such a capability drives the need for research in marketing, OB/HRM, strategy and operations management to be brought to bear on the management and delivery of complex service systems in terms of the configuration of people, physical assets and processes, as well as in the design of the enterprise tasked to achieve it. Compartmentalising the knowledge into individual disciplines may have been useful for the manufacturing and production of goods, where many processes are linear and with low intervention of the customer, but would be less useful in the delivery of complex service systems towards achieving outcomes. 


\section{References}

Albrecht, K., 1992. The only thing that matters. Executive Excellence, 9 (11), 7

Alderson, W., 1957. Marketing behavior and executive action. Homewood: Irwin.

Anderson, J. C. and Narus, J. A.., 1995. Capturing the Value of Supplementary Services. Harvard Business Review, 1995 (January-February), 75-83

Anderson, J. C. and Narus, J. A.., 1998. Business Marketing: Understand What Customer's Value, Harvard Business Review, 1998 (November-December), 53-65

Anderson, J. C., and Narus, J. A., 1999. Business market management: Understanding, creating, and delivering value. Upper Saddle River: Prentice Hall.

Anderson, J. C., Jain, D. C. and Chintagunta. P. K., 1993. Customer Value Assessment in Business Markets: A State of- Practice Study. Journal of Business-to-Business Marketing, 1(1), 3-29.

Barile, S. 2009. Management Sistemico Vitale. Torino, G:Giappichelli.

Barile, S., Polese, F., 2009. Service Dominant Logic and Service Science: a contribute deriving from network teorie. In: E., Gummesson, C., Mele, F., Polese, eds. The 2009 Naples Forum on Service: Service Science, S-D logic and network theory, Napoli: Giannini.

British Standards Institution, 1991. BS 4778-3.1:1991. Quality vocabulary Part 3 Availability, reliability and maintainability terms

Chase, R.B. and Erikson, W.J., 1988. The service factory. The Academy of Management Executive, 2 (3), 191-6.

Chase, R.B., 1978. Where does the customer fit in a service operation?. Harvard Business Review, 56 (6), 137-142

Checkland, P., 1981. Systems Thinking, Systems Practice. John Wiley \& Sons

Checkland, P., Warmington, A. and Wilson, B., 1983. Research on improving the management of production systems: an approach through systems methodology. In: Wilson, Berg and French, The Efficiency of Manufacturing Systems, NATO ARI Series, Plenum, New York, NY.

Chesbrough, H. and Spohrer, J., 2006. A research manifesto for service science. Communications of the ACM , 49 (7), 35-40.

Christopher, M., 1982. Value-in-Use Pricing. European Journal of Marketing, 16(5), 3546.

De Chernatony, L., Harris, F. and Dall'Olmo Riley, F., 2000. Added value: its nature, roles and sustainability. European Journal of Marketing, 34 (1/2), 39-54. 
De Rose, L. J., 1991. Meet Today's Buying Influences with Value Selling. Industrial Marketing Management, 20(2), 87-91.

Defence Standard 00-49, 2008. MOD Guide to R\&M Terminology used in Requirements

Demirkan, H., and Goul, M., 2006. Service oriented technology management to improve organizational agility. International Journal of Innovation and Technology Management 6(1), 1-16

Dooley, D., 2001. Social research methods. Upper Saddle River, New Jersey: PrenticeHall

Doyle, P., 2000. Value-based marketing: Marketing strategies for corporate growth and shareholder value. Chichester: John Wiley \& Sons.

Drucker, P. F., 1974. Management: Tasks, Responsibilities, Practices. New York: Harper \& Row, Publishers Inc.

Golinelli, G. M., 2010. Viable Systems Approach (VSA) Governing Business Dynamics. Milan: Wolters Kluwer Italia Srl.

Grönroos, C., 2001. The perceived service quality concept - a mistake. Managing Service Quality, 11 (3), 150-52.

Gutman, J., 1982. A Means-End Chain Model Based on Consumer Categorization Processes. Journal of Marketing, 46 (Spring), 60-72

Hockley, C.J., 2009. Availability [Course notes]. College of Management and Technology

Hockley, CJ., Smith, J C. and Lacey, L., 2010. Contracting for Availability and Capability in the Defence Environment. In: Complex Engineering Service Systems: Concepts \& Research, forthcoming by Springer

IfM and IBM, 2008. Succeeding through service innovation: A service perspective for education, research, business and government. Cambridge, United Kingdom: University of Cambridge Institute for Manufacturing.

Katz, D. and Kahn, V., 1966. The Social Psychology of Organizations. New York: Wiley. Khalifa, A. S., 2004. Customer value: a review of recent literature and an integrative configuration. Management Decision, 42(5), 645-666.

Lapierre, J., Tran-Khanh, A., and Shelling, J., 2008. Antecedents of Customers' Desired Value Change in a Business-to- Business Context: Theoretical Model and Empirical Assessment. Services Marketing Quarterly, 29(3), 114-148

Lindgreen, A., and Wynstra, F., 2005. Value in business markets: What do we know? Where Are We Going?, Industrial Marketing management, 34(7), 732-748. 
Maglio, P.P., Srinivasan, S., Kreulen, J.T., and Spohrer, J., 2006. Service Systems, Service Scientists, SSME, and Innovation. Communications of the ACM, 49 (7), 81-85

Matthyssens, P. and Vandenbempt, K., 1998. Creating competitive advantage in industrial services. Journal of Industrial and Business Marketing, 13 (4/5), 339-355

Miles, M. B., and Huberman, A. M., 1994. Qualitative data analysis: An expanded sourcebook (2nd ed.). Thousand Oaks, CA: Sage Publications.

Mills, J., Neaga, E., Parry, G., Crute, V., 2008. Toward a framework to assist servitization strategy implementation. Proceedings of the POMS 19th Annual Conference, May 9-12, La Jolla, California

Mullen, J. K., Williams, M., 2004. Maintenance and repair expenditures: Determinants and tradeoffs with new capital goods. Journal of Economics and Business, 56(6), 483499

Neely, A., 2008. Exploring the financial consequences of the Servitization of manufacturing. Operations Management Research, 1 (2), 103-118

Ng, I.C.L., Maull, R., and Yip, N., 2009. Outcome-based Contracts as a driver for Systems thinking and Service-Dominant Logic in Service Science: Evidence from the Defence industry. European Management Journal, 27 (6), 377-387

Ng, I.C. L., Williams, J., and Neely, A., 2009. Outcome-based contracting: Changing the boundaries of B2B customer relationships: An Executive Briefing. Advanced Institute of Management (AIM) Research Executive Briefing Series, (October) http://www.aimresearch.org/index.php?page=alias-3

Ng, I.C.L., and Wild, P., 2009. Research in Service Science. In: The Service Science Handbook: A Research Perspective. Claudio Pinhanez, Wendy Murphy, eds.

Ng, I.C.L., and Nudurupati, S., 2010. Outcome-Based Service Contracts in the Defence Industry - Mitigating the Challenges. Journal of Service Management, 21 (5), 656-674

Ng, I.C.L., Nudurupati, S., and Tasker, P., (2010). Value co-creation in the Delivery of Outcome-based Contracts for Business-to-Business Service. AIM working paper series, 77 (May)

Ng, I.C.L., Maull, R.S., and Smith, L., 2011a. Embedding the New Discipline of Service Science. In: The Science of Service Systems, Demirkan, Spohrer and Krishna, Eds. Service Science: Research and Innovations (SSRI) in the Service Economy Book Series, Springer - ISSN: 1865-4924 
Ng, I.C.L., Badinelli, R., Polese, F., Di Nauta, P., Löbler, H., and Halliday, S., 2011b. SD Logic Research Directions and Opportunities: The Perspective of Systems, Complexity and Engineering. Marketing Theory, Forthcoming

Ng, I.C.L., Parry, G., MacFarlane, D., Wild, P., and Tasker, P., 2011c. Complex Engineering Service Systems: Concepts \& Research, forthcoming by Springer

Oliva, R., and Kallenberg, R., 2003. Managing the transition from products to services. International Journal of Service Industry Management. 14 (2), 160-172

Ostrom, A.L., Bitner, M.J., Brown, S.W., Burkhard, K.A., Goul, M., Smith-Daniels, V., Demirkan, H., and Rabinovich, E., 2010. Moving Forward and Making a Difference: Research Priorities for the Science of Service. Journal of Service Research, Forthcoming

Parasuraman, A., 1997. Reflections on gaining competitive advantage through customer value. Journal of the Academy of Marketing Science, 25 (2), 154-61.

Payne, A., and Holt, S., 2001. Diagnosing customer value: Integrating the value process and relationship marketing. British Journal of Management, 12, 159-182.

Peter, J.P. and Olson, J.C., 1987. Consumer Behavior Marketing Strategy Perspectives. Irwin, Homewood: IL.

Qiu, R.G., 2009. Computational Thinking of Service Systems: Dynamics and Adaptiveness Modeling. Service Science, 1 (1), $42-55$

Ravald, A., and Grönroos, C., 1996. The Value Concept and Relationship Marketing. European Journal of Marketing, 30(2), 19-30

Ren, G., 2009. Service Business Development in Manufacturing Companies: Classification, Characteristics and Implications. $\mathrm{PhD}$ Dissertation, University of Cambridge

Rokeach, M., 1973. The nature of human values. New York: Free Press

Slack, N., Chambers, S., and Johnston, R., 2004. Operations management. Harlow, England: FT Prentice Hall

Smith, A., [1776] 1904. An inquiry into the nature and causes of the wealth of nations. London: W. Strahan and T. Cadell.

Spohrer, J., Maglio, P.P., Bailey, J., and Gruhl, D., 2007. Steps Toward a Science of Service Systems. Computer, 40 (1), 71-7771

Strauss, A., and Corbin, J., 1990. Basics of Qualitative Research: Grounded Theory Procedures and Techniques. Beverly Hills, CA: Sage 
Thomas, D. R. E., 1978. Strategy is different in service business. Harvard Business Review, 56 (4), 158-165

Tzokas, N., and Saren, M., 1999. Value transformation in relationship marketing. Australasian Marketing Journal, 7(1), 52-62.

US National Academy of Engineering, 2003. The Impact of Academic Research on Industrial Performance. National Academies Press

Van Gigch, J.P., 1978. Applied General Systems Theory. New York: Harpercollins

Vandermerwe, S. and Rada, J., 1988. Servitization of business: Adding value by adding services. European Management Journal, 6 (4), 314-324

Vargo, S.L., and Lusch, R., 2004. Evolving to a new dominant logic in Marketing. Journal of Marketing, 68, 1-17

Vargo, S.L., and Lusch, R., 2008. Service-dominant logic: continuing the evolution. Journal of the Academy of Marketing Science, 36 (1), 1-10

Weinberg, G., 1975. An Introduction to General Systems Thinking, Wiley.

Wemmerlov, U., and Hyer, N.L., 1989. Cellular manufacturing in the U.S. industry: a survey of users. International Journal of Production Research, 27 (9), 1511-1530

Wikstrom, S., and Normann, R., 1994. Knowledge and value: a new perspective on corporate transformation. London: Routledge

Wilkie, W.L., 1994. Consumer Behavior, 3rd ed. New York, NY: John Wiley \& Sons

Woodruff R. B., 1997. Customer Value: The Next Source of Competitive Advantage. Journal of the Academy of Marketing Science, 25(2), 139-153

Woodruff, R.B., and Flint. D.J., 2003. Research on Business-to-Business Customer Value and Satisfaction. In: Professor Arch Woodside, ed. Evaluating Marketing Actions and Outcomes (Advances in Business Marketing and Purchasing, Volume 12), Emerald Group Publishing Limited, 515-547

Woodruff, R. B. and Gardial, S.B., 1996. Know Your Customer: New Approaches to Understanding Customer Value and Satisfaction. Cambridge, MA: Blackwell Business Zeithaml, V., 1988. Consumer Perceptions of Price, Quality, and Value: A Means-End Model and Synthesis of Evidence. Journal of Marketing, 52(July), 2-22 


\section{$\underline{\text { Tables }}$}

Table 1 Analysis of interview participants

\begin{tabular}{|c|c|c|c|}
\hline \multicolumn{2}{|c|}{ Provider Participant Analysis } & \multicolumn{2}{|c|}{ Customer Participant Analysis } \\
\hline Roles of Participant & $\begin{array}{l}\text { Number of } \\
\text { participants }\end{array}$ & Roles of Participant & $\begin{array}{l}\text { Number of } \\
\text { participants }\end{array}$ \\
\hline Director & 2 & Director & 3 \\
\hline Head of Services & 4 & Business Manager & 4 \\
\hline General Manager & 1 & $\begin{array}{l}\text { Operations/Project } \\
\text { Manager }\end{array}$ & 5 \\
\hline $\begin{array}{l}\text { Customer Support Centre } \\
\text { Manager }\end{array}$ & 1 & Technical Manager & 1 \\
\hline Supply Chain Manager & 3 & $\begin{array}{l}\text { Supply } \\
\text { Chain/Procurement }\end{array}$ & 3 \\
\hline Programme Director & 1 & Equipment Operative & 2 \\
\hline Programme Manager & 4 & Customer Executive & 3 \\
\hline Programme Executive & 1 & & \\
\hline Customer Executive & 4 & & \\
\hline Equipment/Fleet Manager & 3 & & \\
\hline Total & 24 & Total & 21 \\
\hline
\end{tabular}


Table 2 Recovery Value Proposition Cycle Attributes

\begin{tabular}{|l|l|l|}
\hline Attributes & Attribute Definitions \\
\hline $\begin{array}{l}\text { Technical Query } \\
\text { Response Speed }\end{array}$ & $\begin{array}{l}\text { How quickly it takes the provider to respond to a technical query } \\
\text { raised by a customer and acknowledge it as an item that requires } \\
\text { resolution }\end{array}$ \\
\hline $\begin{array}{l}\text { Technical Query } \\
\text { Resolution Speed }\end{array}$ & The time taken to resolve a technical query raised by a customer \\
\hline Technical Variance & $\begin{array}{l}\text { The issuing of a technical variance to the original design } \\
\text { specification of a part or a repair process to allow for continued } \\
\text { use or repair, enabling a quicker return to operable status of an } \\
\text { asset }\end{array}$ \\
\hline \hline Asset Repair & The return to operable status of an asset for use by the customer. \\
\hline
\end{tabular}


Table 3 Availability Value Proposition Cycle Attributes

\begin{tabular}{|c|c|}
\hline Asset Maintenance & Performing scheduled or preventative maintenance on assets. \\
\hline $\begin{array}{l}\text { Spares Provision } \\
\text { Forecasting }\end{array}$ & $\begin{array}{l}\text { A service to forecast the usage of parts for a particular } \\
\text { customer's equipment to allow for timely provision of the } \\
\text { necessary spares. }\end{array}$ \\
\hline $\begin{array}{l}\text { Facilities Planning \& } \\
\text { Commissioning }\end{array}$ & $\begin{array}{l}\text { Provision of advice and design skills for customer required } \\
\text { facilities }\end{array}$ \\
\hline $\begin{array}{l}\text { Equipment Life } \\
\text { Assessment/Management } \\
\text { Planning }\end{array}$ & $\begin{array}{l}\text { Provision of equipment life advice in order to maximise the } \\
\text { potential use at minimum cost. }\end{array}$ \\
\hline $\begin{array}{l}\text { Availability Forecasting } \\
\text { and Planning } \\
\text { Recommendations }\end{array}$ & $\begin{array}{l}\text { Advisory service to ensure optimised and/or specified equipment } \\
\text { availability at minimum cost. }\end{array}$ \\
\hline $\begin{array}{l}\text { Equipment Obsolescence } \\
\text { Management Support }\end{array}$ & $\begin{array}{l}\text { Obsolescence monitoring and assessment service to manage } \\
\text { potential supply chain hazards and help mitigate disruption to a } \\
\text { customers operation. }\end{array}$ \\
\hline $\begin{array}{l}\text { Working Asset Level } \\
\text { Support }\end{array}$ & $\begin{array}{l}\text { Advisory service on the number of spare assets needed in order } \\
\text { to support specified equipment availability month to month. }\end{array}$ \\
\hline $\begin{array}{l}\text { Asset Use/Maintenance } \\
\text { Advice }\end{array}$ & $\begin{array}{l}\text { Advisory service on how best to use and not use an asset and } \\
\text { how to maintain it to achieve the optimal asset output. }\end{array}$ \\
\hline
\end{tabular}


Table 4 Outcome Value Proposition Cycle Attributes

\begin{tabular}{|l|l|}
$\begin{array}{l}\text { Optimal configuration } \\
\text { for the use of total } \\
\text { availability }\end{array}$ & $\begin{array}{l}\text { Help and advice on how best to optimise configuration of } \\
\text { equipment dependent on the operational requirement a customer } \\
\text { may have }\end{array}$ \\
& $\begin{array}{l}\text { e.g. - these assets, with this availability, in this combination to } \\
\text { allow capability for X }\end{array}$ \\
\hline $\begin{array}{l}\text { Optimal configuration } \\
\text { advice for outcome } \\
\text { capability }\end{array}$ & $\begin{array}{l}\text { Help and advice on how best to configure equipment (to be used } \\
\text { with other equipment) to achieve better outcomes }\end{array}$ \\
& $\begin{array}{l}\text { e.g. - these assets, with this availability, in this combination with } \\
\text { other equipment to achieve a capability (that could be variable in } \\
\text { nature) in an optimized manner }\end{array}$ \\
\hline
\end{tabular}


Table 5 Summary of findings on value proposition cycles of equipment based service

\begin{tabular}{|l|l|l|l|}
\hline & $\begin{array}{c}\text { Recovery Value } \\
\text { Proposition Cycle }\end{array}$ & $\begin{array}{l}\text { Availability Value } \\
\text { Proposition Cycle }\end{array}$ & $\begin{array}{c}\text { Outcome Value } \\
\text { Proposition Cycle }\end{array}$ \\
\hline Value Proposed & $\begin{array}{l}\text { Minimum disruption } \\
\text { when equipment fails }\end{array}$ & $\begin{array}{l}\text { Maximum } \\
\text { availability of } \\
\text { equipment }\end{array}$ & $\begin{array}{l}\text { Better capability to } \\
\text { achieve outcomes }\end{array}$ \\
\hline $\begin{array}{l}\text { Primary } \\
\text { Transformation }\end{array}$ & Material & Information & Customer \\
\hline
\end{tabular}




\section{Figures}

Figure 1 Enterprise Model (Adapted from Checkland et al., 1983)

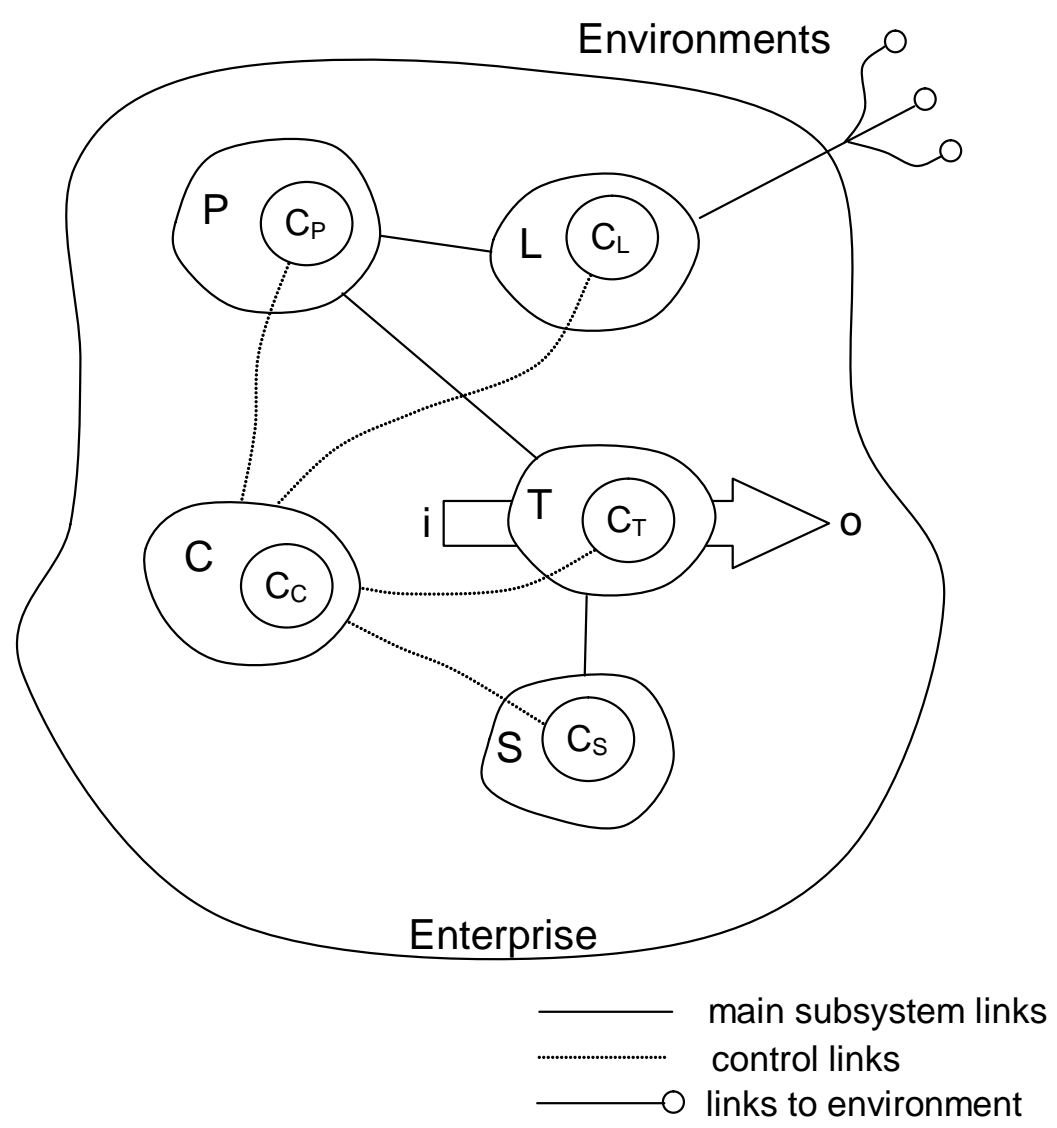


Figure 2 Management Control System (Checkland et al., 1983)

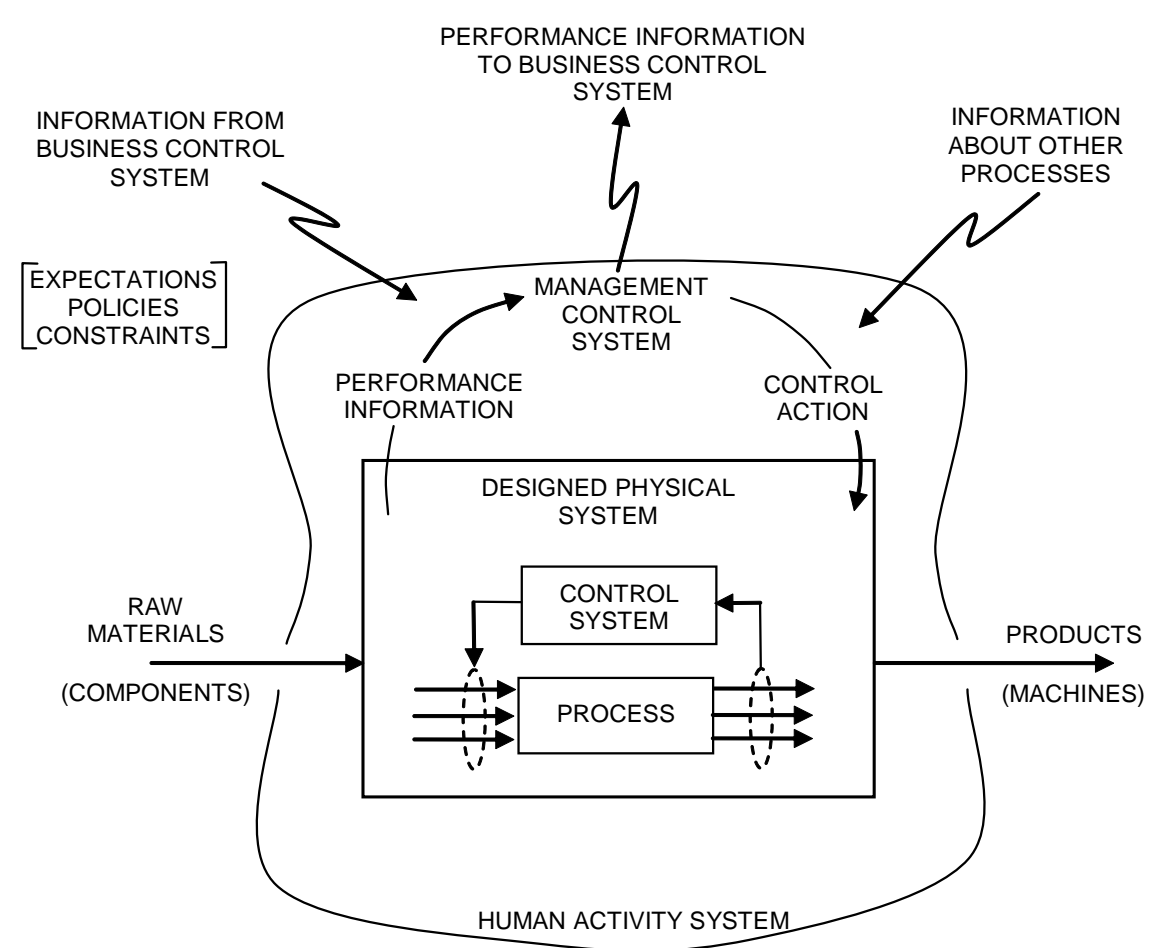


Figure 3 Customer Value Hierarchy Model (Woodruff, 1997. P. 142)

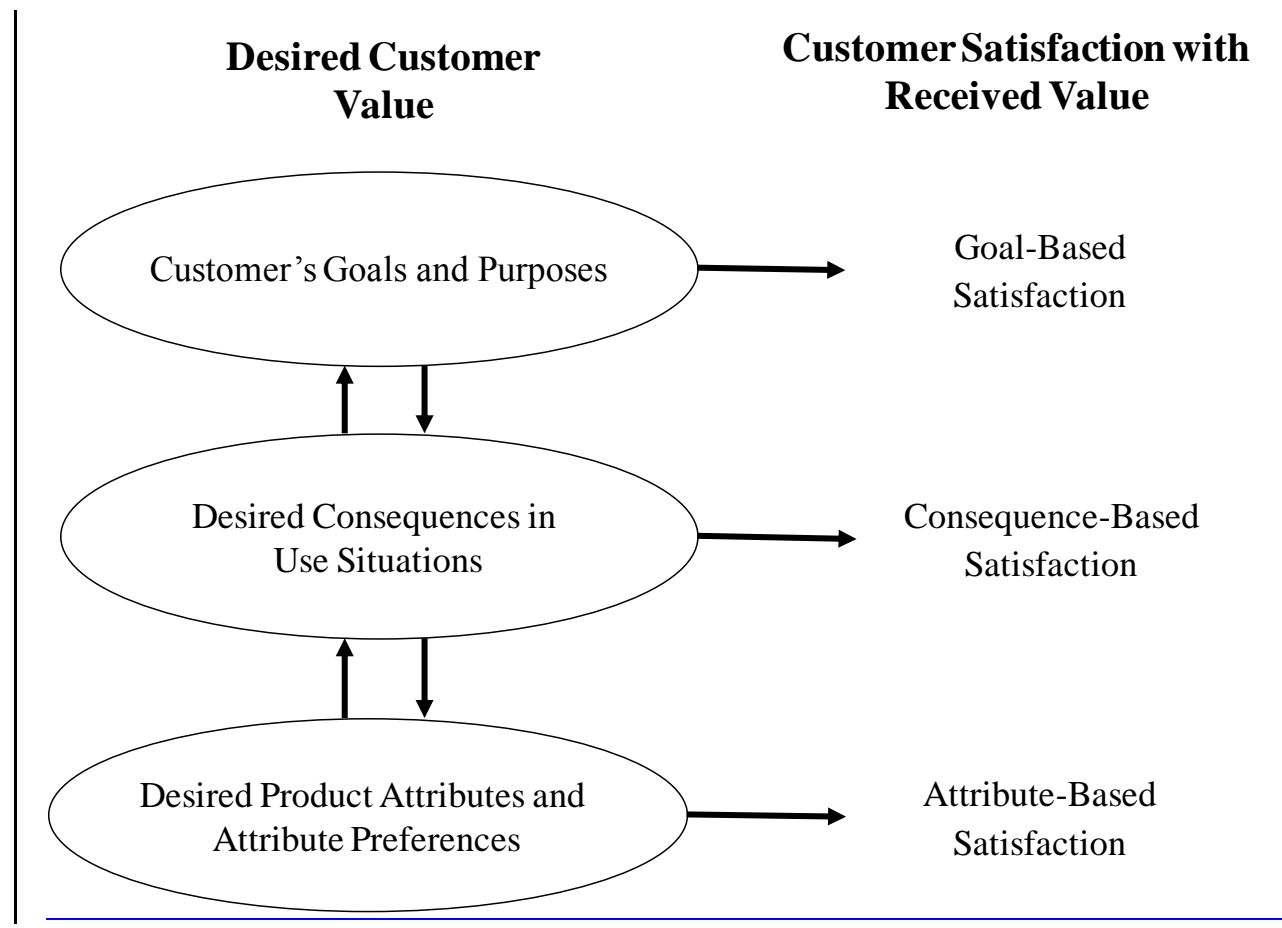


Figure 4 Three Value Proposition Cycles of Equipment Based Service

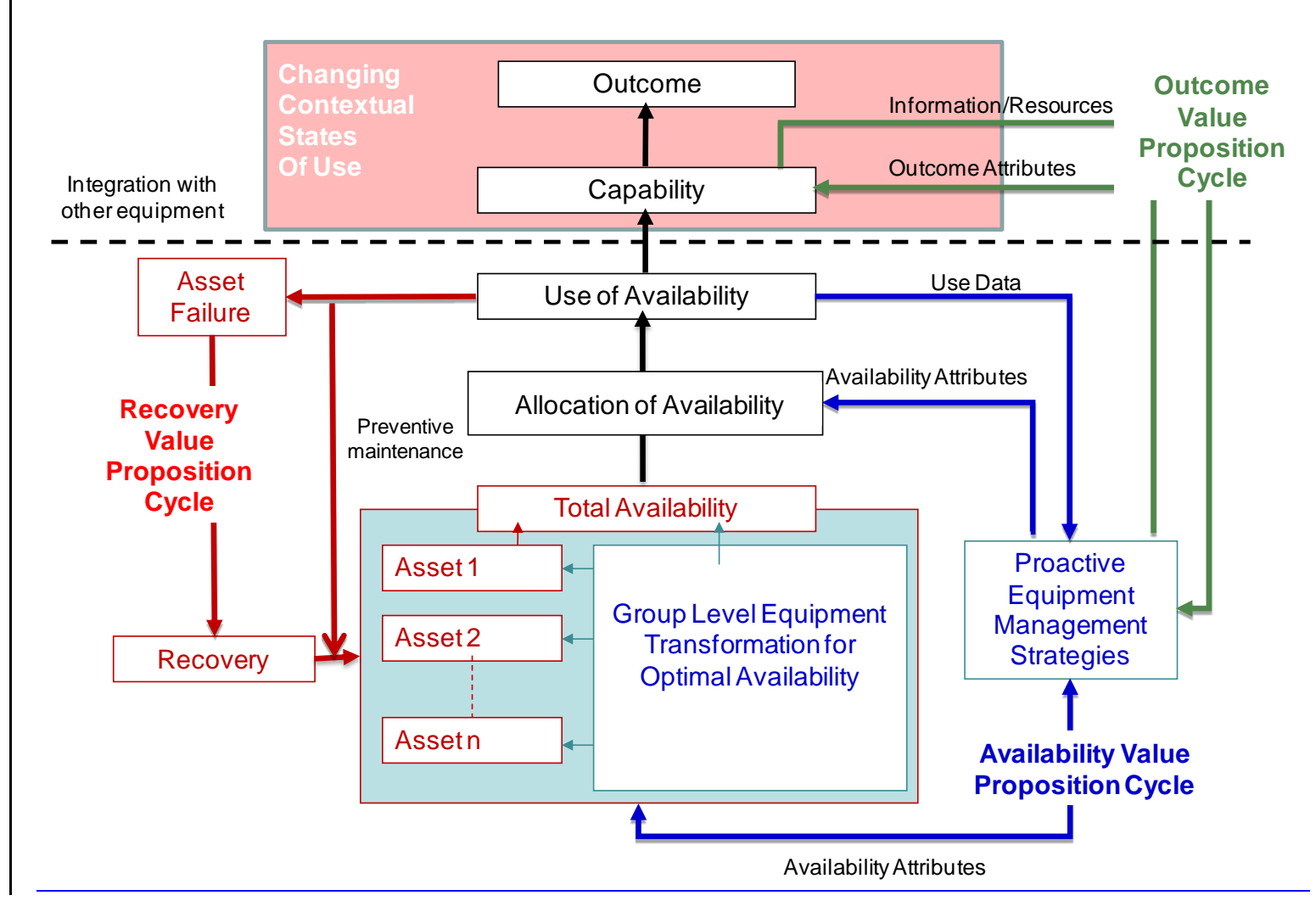

